\author{
Кравченко Ганна Юріївна \\ Харківський національний економічний університет \\ імені Семена Кузнеця
}

\title{
АДАПТИВНЕ УПРАВЛІННЯ: МОЖЛИВОСТІ ТА СПЕЦИФІКА АДАПТИВНОГО УПРАВЛІННЯ РОЗВИТКОМ
}

У статті розглянуто питання адаптивного управління розвитком вищих навчальних закладів. Визначено, що система управління формує або активізуе потенціал закладу, спрямовуючи його розвиток. Уточнено можливості та специфіку адаптивного управління соиіально-педагогічними системами, які впливають на управління розвитком вищих закладів освіти. Зазначено, що адаптивне управління визнає пріоритет розвитку об'єкта (суб'єкта) $i$ здійснюється за допомогою прочесів самоорганізаиії. Звернено увагу на загальні закони розвитку, що приводять до змін у діяльності всіх структурних підрозділів кафедральної системи вищих закладів освіти. Акцентовано увагу на тому, щзо одним із основних призначень соиіального управління є регулювання спільної діяльності людей шляхом цілеспрямування й самоорганізаиії для задоволення власних потреб та потреб розвитку кафедральної системи вищих закладів освіти. А можливості адаптивного управління передбачають розвиток через якісні та кількісні зміни кафедральної системи та самої організаиії.

Ключові слова: адаптивне управління, адаптивне управління розвитком, сочіально-педагогічні системи, кафедральна система, вищий заклад освіти.

Проблема, їі зв'язок із важливими науковими чи практичними завданнями. Основними складовими будь-якого вищого навчального закладу, незалежно від його розміру, сфери функціонування та завдань, які він вирішує, є суб'єкти діяльності (керівники, викладачі, аспіранти, студенти, слухачі, обслуговуючий персонал) та система управління, що формує або активізує потенціал закладу, спрямовуючи його розвиток. Важливого значення для нашого дослідження набувають питання управління адаптивними системами у сфері освіти, зокрема: дослідження адаптивного управління педагогічними системами П. Третьякова, С. Мітіна, Н. Бояринцевої; створені педагогічні технології адаптивної школи М. Капустіна i 
технології адаптивного управління Г. Єльникової, Г. Полякової, В. Петрова, І. Лапшиної.

Ціль статті полягає у розкритті особливостей законів розвитку, специфіки та можливостей адаптивного управління розвитком соціально-педагогічних систем.

Аналіз публікацій (виділення невирішених проблем). Безліч цілей i завдань, що стоять перед кафедрами та структурними методичними підрозділами вищих закладів освіти, приводить до того, що для управління ними потрібні спеціальні знання, методи та прийоми, які забезпечують результативну спільну діяльність співробітників усіх структурних підрозділів кафедральної системи, оскільки кожна кафедра і кожен методичний підрозділ має, як правило, загальні та власні цілі, для досягнення яких потрібні досягнення проміжних цілей. Результати аналізу теоретико-методологічних основ адаптивного управління (В. Афанасьєв, Г. Сльникова, Т. Борова, Т. Давиденко, М. Капустін, О. Касьянова, І. Лапшина, В. Луговий, В. Петров, Г. Полякова, I. Пригожин, К. Райхерт, 3. Рябова, Г. Сухович, Л. Фесік, Т. Шамова, Є. Ямбург) дозволяють виокремити його особливості й ознаки.

Виклад основного матеріалу, обгрунтування результатів дослідження. Адаптивне управління визнає пріоритет розвитку об'єкта (суб'єкта) і здійснюється за допомогою процесів самоорганізаичї.

Адаптивне управління - це форма й методи управління організаційними структурами, які передбачають можливість і здатність системи управління змінювати параметри та структуру регулювання й підсистеми, що управляє, в цілому залежно від зміни внутрішніх параметрів об'єкта управління або зовнішнього середовища, а також від змін стратегічних цілей [2].

Для визначення впливу адаптивного управління на розвиток вищих закладів освіти необхідно звернутися до загальних законів розвитку.

Закон структурного перетворення витікає із загальної теорії організацї та дезорганізації [1]. Відповідно до цієї теорії зміни починаються $з$ порушення рівноважного стану системи при здійсненні зовнішнього впливу. Функціонування кафедральної системи передбачає вплив на діяльність іï підсистем (кафедр/методичних структурних підрозділів) адміністративного рівня управління. Кожен із проректорів, виставляючи певні задачі перед структурними підрозділами, своїми вимогами спонукає їх перебудовувати свою діяльність, створюючи мережну взаємодію між собою для виконання поставлених задач. Таким чином, виникає необхідність у розробці програми спільних дій, до розроблення якої залучаються ті структурні 


\section{Збірник наукових статей}

підрозділи кафедральної системи (КС), інтереси, яких збігаються. Відбувається самоорганізація процесу діяльності в умовах КС (узгоджується мета, визначаються спільні завдання, упродовж реалізації яких коригуються часткові цілі, організація спільної діяльності).

Закони розходження та сходження форм, ще розкривають природу розвитку. Сам розвиток виникає через появу та посилення відмінностей, спрямованих на встановлення додаткових зв'язків для забезпечення більшої стійкості форм. Поява додаткових відносин характеризується своєю необоротністю, бо виникнення чогось нового відбувається завдяки руйнуванню чогось старого. Системне розходження розвиває певні умови нестійкості, створюючи підгрунтя для розвитку системних протиріч. Наступним кроком є зростання організаиійних відмінностей між частками иілого. Вирішення системних протиріч відбувається шляхом узгодження мети, кон'югаційних процесів, які зближують частки цілого, утворюючи нову зв'язку. Це процес сходження форм, який призводить до їх поєднання й утворення нової єдності. Таким чином, процес системного розходження має подвійну сутність, яка полягає у розвитку системи до більшої стійкості форм через додаткові зв'язки з обов'язковим наступним їх розривом через накопичення нових протиріч [1].

Отже, фаза системної диференціації замінюється фазою системної консолідащіï. У процесі розвитку ці фази постійно чергуються. Призупинка чергування призупиняе розвиток.

Взагалі система зберігається за рахунок підтримки динамічної рівноваги 3 середовищем шляхом установлення двох потоків активностей:

- поглинаючого потоку, що переходить із середовища у середину системи;

- випромінюючого потоку, який утрачає активності, що переходять у зовнішнє середовище із середини системи [1].

Ці процеси регулюють розвиток системи у напрямку більш стійких відносин. Розвиваються такі відмінності, які підвищують зв'язність, організованість, структурну стійкість системи та їі міцність під зовнішнім впливом. Установлюються додаткові зв'язки, які ніколи не бувають досконалими, тому що обмін активностями ніколи не доходить до кінця.

У нашому дослідженні під розвитком кафедральної системи вищих закладів освіти ми розуміємо процес, унаслідок якого відбуваються позитивні зміни й перехід системи у новий якісний стан [2]. Основою розвитку є вирішення суперечностей. Природно це відбувається шляхом зближення різних точок зору через їх діалогічне узгодження на основі когерентності (єдності походження). Ефективне 
спрямування розвитку шляхом діалогічної адаптації можна здійснити двома способами: це насичити простір, де рухається людина, потрібними суспільству, державі «випадковостями», або визначити параметри, фактори руху і скласти адаптивні моделі діяльності, забезпечити їх адаптацію «на себе» кожним виконавцем. Процес діяльності «відпустити» на вільний розвиток, використовуючи поточний самоаналіз i самокоригування. Зовнішній контроль i прогнозування проводити тільки за результатом. При цьому коригування процесу за результатом не проводиться, адже природний розвиток необоротний. Коли він відбувся, можна говорити тільки про прогнозування подальшого розвитку [2].

У своєму дослідженні ми розглядаємо поняття «управління розвитком» соціально-педагогічних систем, здатних до рефлексії [3]. Управління розвитком у такому випадку набуває соціальної характеристики.

Одним 3 основних призначень соціального управління $\epsilon$ регулювання спільної діяльності людей шляхом цілеспрямування й самоорганізації для задоволення власних потреб та потреб розвитку кафедральної системи вищих закладів освіти (табл. 1).

Таблиия 1

Специфіка адаптивного управління розвитком кафедральної системи

\begin{tabular}{|l|l|ll|}
\hline $\begin{array}{l}\text { № } \\
\text { 3/п }\end{array}$ & \multicolumn{1}{|c|}{$\begin{array}{c}\text { Можливості } \\
\text { адаптивного } \\
\text { управління }\end{array}$} & \multicolumn{3}{|c|}{ Розвиток через якісні та кількісні зміни } \\
кафедральної системи
\end{tabular}


Продовж. табл. 1

\begin{tabular}{|c|c|c|}
\hline 2. & $\begin{array}{l}\text { Застосування } \\
\text { керівниками коучингу } \\
\text { як механізму } \\
\text { спрямованої } \\
\text { самоорганізації, } \\
\text { допомагає самостійно } \\
\text { усвідомлено } \\
\text { прийняти рішення та } \\
\text { діяти у напряму } \\
\text { досягнення мети }\end{array}$ & $\begin{array}{l}\text { Через впровадження технологій навчання на } \\
\text { основі коучингу - «активне навчання» та } \\
\text { «навчання через зворотний зв'язок»: } \\
\text { - усвідомлення навчальної ситуації } \\
\text { студентом/слухачем за допомогою викладача, } \\
\text { який не втручаючись у навчальну діяльність, } \\
\text { надає можливість зробити найкращий вибір та } \\
\text { самостійно прийняти рішення; таким чином } \\
\text { через дію відбувається усвідомлення того, } \\
\text { чого студент/слухач намагається досягти; а } \\
\text { зміни, що спрямовані на майбутнє } \\
\text { спостерігаються в управлінні власними } \\
\text { знаннями - основним регулятивним } \\
\text { компонентом розвтку професіоналізму } \\
\text { (якісні зміни). }\end{array}$ \\
\hline 3. & $\begin{array}{l}\text { Поєднання зусиль } \\
\text { керівників і } \\
\text { виконавців }\end{array}$ & 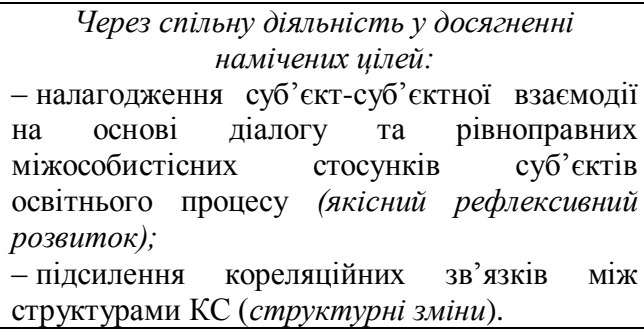 \\
\hline 4. & $\begin{array}{l}\text { Узгодження } \\
\text { різноспрямованих } \\
\text { впливів }\end{array}$ & $\begin{array}{l}\text { Відбувається за допомогою } P R-\text { технологій } \\
\text { та методу Дельфi: } \\
\text { - всі учасники кафедральної системи мають } \\
\text { своє власне бачення вирішення поставлених } \\
\text { завдань, тому виникаюча необхідність } \\
\text { висловлення своїх думок, їх обгрунтування та } \\
\text { сумісного обговорення прогнозованих } \\
\text { результатів, надає можливість для } \\
\text { узгодженого сумісного п прийняття } \\
\text { різносторонніх рішень щодо перспективи } \\
\text { подальшого розвитку (якісний рефлексивний } \\
\text { pозвиток). }\end{array}$ \\
\hline 5. & $\begin{array}{l}\text { Спрямування } \\
\text { діяльності у } \\
\text { відповідності зі } \\
\text { змінами вимог ринку } \\
\text { освітніх послуг та } \\
\text { ринку праці } \\
\text { маркетингово- } \\
\text { моніторингові } \\
\text { дослідження }\end{array}$ & $\begin{array}{l}\text { Через зміни в управлінні: } \\
\text { - створення інформаційного маркетингово- } \\
\text { моніторингового центру для аналізу та } \\
\text { прогнозування змін у подальшій діяльності } \\
\text { (структурні зміни); } \\
\text { - підвищення самостійності в поточному } \\
\text { регулювання діяльності на основі рефлексії } \\
\text { (якісний рефлексивний розвиток). }\end{array}$ \\
\hline
\end{tabular}


Висновки, перспективи. Отже, враховуючи все вищезазначене, можна дійти висновку, що використання адаптивного управління розвитком вищих навчальних закладів у сучасних умовах приводить до змін в їх діяльності, а саме: зумовлює мобільний підхід до формування організаційної структури кафедральної системи та мобільність у відкритті нових підсистем кафедри; поєднання зусиль всіх підсистем кафедри для реалізації завдань та цілей; виявлення результативності шляхом зовнішнього контролю i самоконтролю, спільне прогнозування напрямів подальшого розвитку; трансформацію зовнішніх вимог у внутрішні мотиви методом переконання і спільної діяльності 3 вибору напрямку подальшої дії; створення та використання факторно-критеріальних моделей управління та професійної діяльності.

Таким чином розглянувши сутнісну характеристику адаптивного управління, визначивши його специфіку у напрямі управління розвитком зазначимо необхідність подальшого дослідження специфіки закономірностей, принципів та методів адаптивного управління розвитком кафедральної системи вищих закладів освіти.

\section{Література}

1. Богданов А. А. Тектология. Всеобщая организационная наука: Кн. 1 и 2. - М. : Экономика, 1989. - 655 с.

2. Сльникова Г. В. Основи адаптивного управління : курс лекцій / Г. В. Сльникова. - Х. : Вид. гр. «Основа», 2004. - 128 с.

3. Кравченко Г. Ю. Теоретичні засади адаптивного управління розвитком кафедральної системи інститутів післядипломної педагогічної освіти України / Г. Ю. Кравченко // Spatial aspects of socio-economic systems development: the economy, education and health care. Monograph. Opole: The Academy of Management and Administration in Opole, 2015; ISBN 978-83-62683-63-5 (Paper); pp. 300, illus., tabs., bibls.

\section{Анна Кравченко Адаптивное управление: возможности и специфика адаптивного управления развитием.}

В статье рассмотрены вопросы адаптивного управления развитием высших учебных заведений. Определено, что система управления формирует или активизирует потенциал учреждения, направляя его развитие. Уточнень возможности и специфика адаптивного управления сочиально-педагогическими системами, которые влияют на управление развитием высших учебных заведений. Отмечено, что адаптивное управление признает приоритет развития объекта (субъекта) и осуществляется с помощью процессов самоорганизации. 


\section{Збірник наукових статей}

Обращено внимание на общие законы развития, которые приводят к изменениям в деятельности всех структурных подразделений кафедральной системы высших учебных заведений. Акцентировано внимание на том, что одним из основных назначений сочиального управления является регулирование совместной деятельности людей путем иеленаправленности и самоорганизачии для удовлетворения собственных нужд и потребностей развития кафедральной системь высших учебных заведений. А возможности адаптивного управления предусматривают развитие через качественные и количественные изменения кафедральной системы и самой организаџии.

Ключевые слова: адаптивное управление, адаптивное управление развитием, сочиально-педагогические системы, кафедральная система, высшее учебное заведение.

\section{Hanna Kravchenko. Adaptive management: the opportunities and specifics of adaptive development management.}

The article deals with the problems of adaptive management of the development of higher education institutions. It is determined that the management system forms or activates the institution's potential, directing its development. The possibilities and specifics of adaptive management of social-pedagogical systems that influence the management of the development of higher educational institutions are specified. It is noted that adaptive management recognizes the priority of the development of the object (subject) and is carried out through the processes of selforganization. The attention is drawn to the general laws of development, which leads to changes in the activities of all structural units of the cathedral system of higher educational institutions. The emphasis is placed on the fact that one of the main purposes of social management is the regulation of joint activities of people through targeting and selforganization to meet their own needs and needs for the development of the cathedral system of higher educational institutions. And the possibilities of adaptive management involve development through qualitative and quantitative changes of the cathedral system and the organization itself.

Keywords: adaptive management, adaptive development management, social-pedagogical systems, cathedral system, higher education institution.

Стаття надійшла до редакційної колегії 10.10.2017

\section{Інформація про автора:}

Кравченко Ганна Юріївна - доктор педагогічних наук, доцент, Харківський національний економічний університет імені Семена Кузнеця. 